\title{
ANALYSIS OF DESIGN AND IMPLEMENTATION OF INFORMATION SYSTEM OF LIBRARY OF UIN SUNAN KALIJAGA JOGYAKARTA
}

\author{
Hendra Junawan \\ Mahasiswa Pascasarjana Universitas Islam Negeri Sunan Kalijaga \\ Yogyakarta \\ Kosentrasi Ilmu Perpustakaan Dan Informasi \\ hendrajunawan2@gmail.com
}

\begin{abstract}
The purpose of writing this article is to find out how to design and implement the Information System of the Sunan Kalijaga State Islamic University Yogyakarta Library which is supported by the System Development Life Cycle (SDLC). The method used in this study is the type of field research that is "field research" which has the nature of skin research and data collection techniques with direct observation and information obtained through documentation in the field. The results and discussion in this article show that CYPRUS (Library Information System) has the task of collecting, processing, preserving, reinventing information, borrowing and returning books in the circulation section, already using information technology to store data and library collections, in the design process This library information system also uses the MySQL database in streamlining the library information system, and from the plan, it can be used by the admin and librarian and the results are shown in the library information system design show that there is data collection on the members, login columns, member data types, display reports free library, and display collection returns and borrowing columns.
\end{abstract}

Keywords: Design and Implementation, Library Information System. 


\section{A.INTRODUCTION}

Today's technological advancements have become a topic of discussion among the world community and so is the world of libraries along with the development of the times so that they will be balanced and able to transform in providing information, serving, and processing information.

In this case, the library can also be defined as a collection of books or collections of various forms on communication media, such as manuscripts, magazines, books, brochures, newspapers, microfilm, films, CD-ROMs, and videos. In the current era of information technology, databases in electronic media are considered as library collections. Various communication media library collections are collections of library materials now, the database in electronic media is considered as a library collection. Various communication media library collections, collections of library materials are collected, well organized, and regulated by systems used for education, research, for information materials, and healthy intellectual recreation for the community.

The growing development of information technology today makes users able to take advantage of the progress of information technology. From the desire to move forward, libraries can utilize information technology that is as sophisticated as it is today, to be applied in libraries today and beyond. In presenting information in the library, the library applies information technology applications in libraries that have been well designed to make it easier for users to access information.

Through the provision of library material services for library visitors in various fields of information both through printed and recorded media that have educational characteristics. Now addressing the above it can be seen that the purpose of this study is to find out how the design and design of information systems contained in the Sunan Kalijaga Yogyakarta Yogyakarta UIN 
Library that can be believed that can increase knowledge for library/library visitors, skills, and broaden the horizons of knowledge and information for education, research, and as a vehicle for the intellectual life of the nation, especially the users. Based on the explanation above, the researcher is interested in raising the title "Analysis of Design and Implementation of Information Systems Design of Uin Sunan Kalijaga Library in Yogyakarta"

\section{B. THEORY STUDY}

The library is an institution that is very at war in storing, deceiving, and distributing information to users effectively and efficiently. Basically, an information system is a collection of elements that are interrelated with one another, which forms a single unit to integrate data, process, and store and distribute information. Data is a collection of events raised from an event. Data processing is a useful and meaningful form of information. Information is the result of data processing activities that provide a more meaningful form of an event.

\section{Definition of Design and System}

The system is a collection of components that are considered interrelated from one and the other so that they form one of the concepts and frameworks in the process of achieving a common goal. Now, with planning, we can define something as an activity or a selection process and thoughts that can connect a fact-based on assumptions related to the future and formulate a concept in order to achieve a certain goal (Speed \& Engineering, 2010).

\section{Information Systems}

The information system is a series of formal procedures in which data is grouped, processed into information, and 
distributed to users. Information systems include a number of components, human resources, information technology, and work procedures, something that is processed into data that becomes information and is intended to achieve a goal or goal.

An information system is a collection of hardware, software, Brainware, procedures, and or rules that are integrally organized to process data into useful information to solve problems and return decisions. The information system is a collection of sub-systems both physical and non-physical that is interconnected between one another and works together in harmony to achieve a goal that is processing data into useful information for users. In the context in the library that the system components consist of, a. "Hardware" hardware, including physical devices, b. Software "software" or program, a set of instructions that allows hardware to be able to process data, c. The procedure, a set of rules used to realize the desired data processing and output generation, $\mathrm{d}$. All parties are responsible for developing information systems, processing, and using information system outputs, e. Database "database", a collection of tables, relationships, and others relating to data storage, f. A computer network, g. Data communication, a liaison system that enables resources to be shared or accessed by a number of users.

Information systems are frameworks that coordinate resources (human, computer) to convert inputs into outputs (information), in order to achieve company goals (Nugraha et al., 2014) In library information systems consisting of the indexing process "indexing" "Are all processes related to subject analysis, classification, and cataloging. And the process of information retrieval is the process of finding 
library material through a library catalog or information search.

\section{Library Information System}

The library information system is something every activity in the library world using information technology coupled with information sources such as journals, electronic books, and the results of the scanning of information sources that have been transferred. Well, the library information system also requires processing, and preservation of junk files so that it does not make the system slow or slow. A library information system is also very easy in the process of accessing it so that library users do not wait a long time in the process of finding information (Alifah \& Cahyo, 2018)

\section{Methods in the System Development Life Cycle}

In today's System Development Life Cycle is a picture of the results of a business that is designed by a system that always moves like a wheel that continues to pass through steps and stages, such as "investigate, analyze, design, implementation, and maintenance".

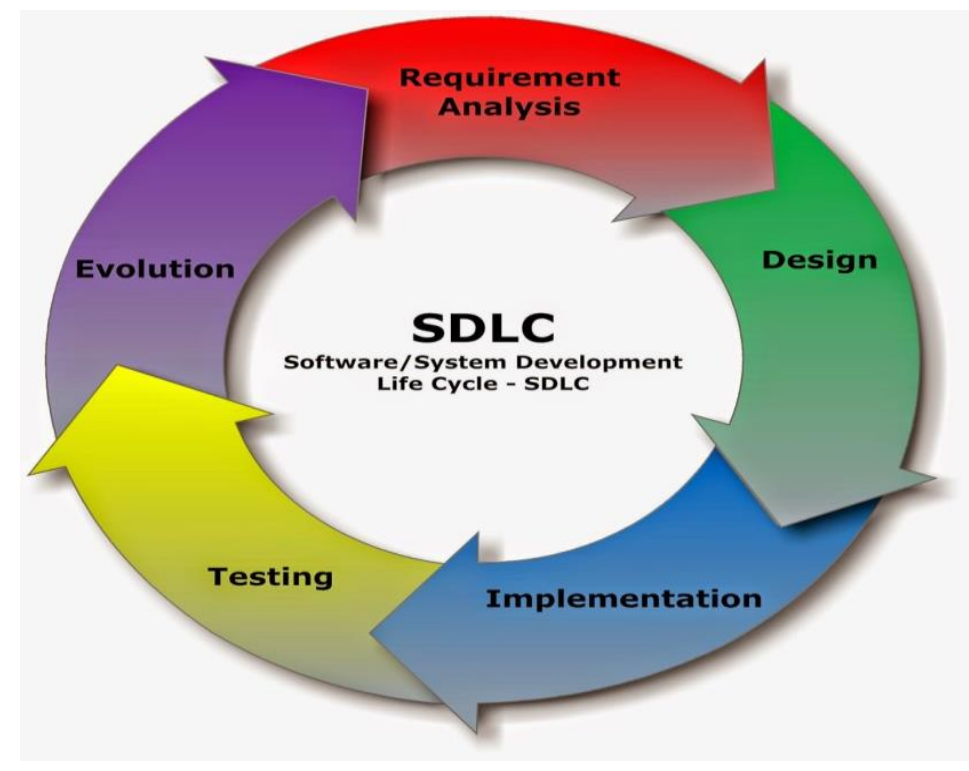


Figure 1. Information System Development Stages

(Dahlan Abdullah, 2017) It is the initial stage of system development, this stage aims to identify and prioritize what information systems will be developed, the goals to be achieved, the duration of implementation and consider the available funds and who is implementing.

\section{A. Investigation Stage or Planning Stage}

The initial investigation or planning stage in a study of system development by applying the following stages:

1. Defining the problems/problems encountered in the system

After getting into trouble, the management must be able to resolve the problem at hand. At this stage managers must work together on system analysis, to be able to identify the problem at hand.

1. Able to overcome general difficulties

A manager works closely with system analysis in making a reference list about the purpose of the system to get by the system, all this for user satisfaction.

2. Able to make a feasibility study

a. Technical, providing hardware and software in implementing the processing that is needed.

b. Economic returns, the system is submitted financially and can compare costs and finances.

c. The proposed system is capable of being supported by legal and ethical restrictions. 
d. Building a system design supported by professional human resources.

e. Able to implement the system with a predetermined time.

3. Able to prepare regarding system research proposals.

After the system is considered feasible, therefore the need for a thorough system research. In the analysis of the system must prepare a research system that can provide a basis for managers.

\section{B. Analysis Phase}

1. Announce the research system

At the time of the research announcement, the management party was able to make decisions about the steps in ensuring cooperation with employees. By explaining the development that will benefit the manager and the agency.

2. Defining user information needs

Able to learn the information needs of users, by studying the information needs of users in a variety of activities about information gathering through the interview stage conducted.

3. Prepare the proposed activity plan.

4. Analyze the proposed work system.

\section{Stage in System Design Design}

The benefits of system design are being able to give an idea of a complete building design, to be a tool for programmers in developing applications. 
1. Able to prepare a structured system design or system logic design.

2. Able to identify from various alternatives about system configuration. Make a list of concrete specifications about hardware and software to get the best results for the system.

a. Stage of System Implementation

Implementation is an activity / activity in identifying physical and conceptual resources in getting the results of a system that works, to plan implementation, be able to get hardware resources, make announcements in the system implementation, get resources from software, prepare physical facilities, prepare databases, library training, and enter the new system

b. System maintenance stage

To use the system, it is necessary to maintain the system, to correct problems, maintain the authenticity of system updates, and being able to improve the system.

\section{Strengths and weaknesses SDLC}

(Samiji Sarosa, 2017) Development of information systems of various sizes and levels of complexity, some of the advantages of SDLC, as follows:

1. The existence of standard documentation standards, the existence of standard documentation facilitates communication between stakeholders of information systems. Documentation also ensures 
that the specification of the system developed has been recorded and can be built.

2. Complete documentation also makes it easy for education for system users.

3. SDLC has included tools for project management, SDLC has stages with cutover limits and artifacts in the form of clear reports and results. The stages make it easier to manage information systems development projects because the steps are clearly defined.

Even though SDLC has had more than 50 years of practice in it, several weaknesses in the SDLC were found, as follows:

1. Not able to meet management needs, in general, the system built by SDLC is a transaction management system. This system meets the needs of the operational managerial level at the very bottom. Most of the system information at the operational level is tasked with handling and processing data on routine and recurring transactions.

2. Modeling unstable processes, in SDLC the analysis is done by observing the running business processes and then designing new and better business processes.

3. Design is not flexible, in SDLC the design of a new system is based on the output of the information system.

4. The dissatisfaction of the visitors, not the monopoly of the SDLC system. 
5. Documentation issues, although SDLC has introduced documentation standards, such as Data Flow Diagrams and Flowcharts, in practice these are inadequate.

6. Lack of control, embedded in project management tools SDLC, making estimates, and also project control is not easy.

7. An incomplete system, computers are very good at managing large amounts of data at high speed. Computers are very superior in structured, routine, and not much variation data processing.

8. Application development queues, when SDLC is widely used, at the same time there is an increase in the intensive and extensive use of computers.

9. The workload maintenance system, as a result of the long waiting time for the completion of the development of the system, is the developer trying to speed up work.

10. Problems with the ideal approach.

11. Emphasis on the technical approach, SDLC was developed by programming and computer experts.

12. The assumption that the system is made from a completely new condition.

The weaknesses of SDLC above are potential, meaning that when using SDLC, development needs to pay attention and anticipate the weaknesses listed above.

\section{C.RESEARCH METHOD}

This study is a type of field research that is "field research" which has the nature of qualitative research. Researchers collected information at the research location regarding the implementation of the information system of the Yogyakarta UIN Sunan Kalijaga 
Library. In each study, a researcher must have a good plan, for the concept of conducting research. In this scaffolding, researchers used a descriptive qualitative research type using the case study method. According to Bogdan and Taylor, the type of qualitative research is the result of descriptive data in the form of written data and words. (Sugiono, 2008), Qualitative research has the objective to obtain the overall results of the description of an issue from the researcher. Researchers are trying to give a complete picture of the design of library information systems in the Library. This study will provide the results of the conditions in the study and the conditions under study so that researchers will provide research reports.

\section{D.DISCUSSION}

In the process of drafting the concept and design of the library information system design, it is necessary to have a picture such as a diagram, the concept of system design that can be proposed in the system design process. Activities that can be proposed in this case such as:

\section{Context Diagram}

Context Diagram is a general description of a library information system consisting of several terminators which are at war with the provision of information needs for users generated by the library information system.

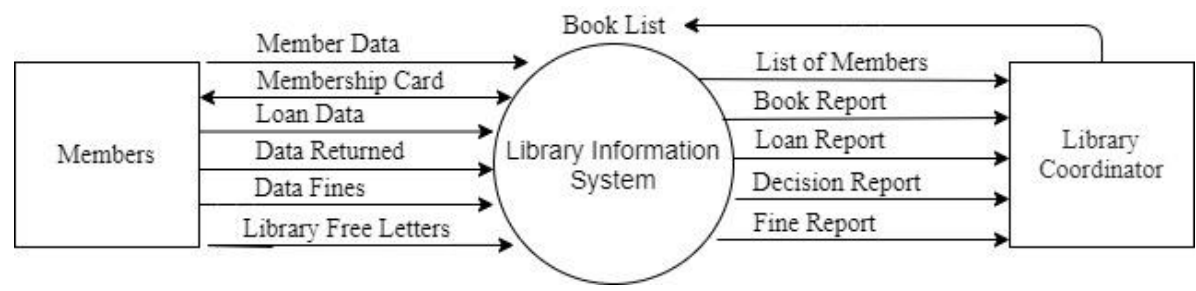

Figure 2. Library Information System Context Diagram 
2. Decomposition of Library Information Systems

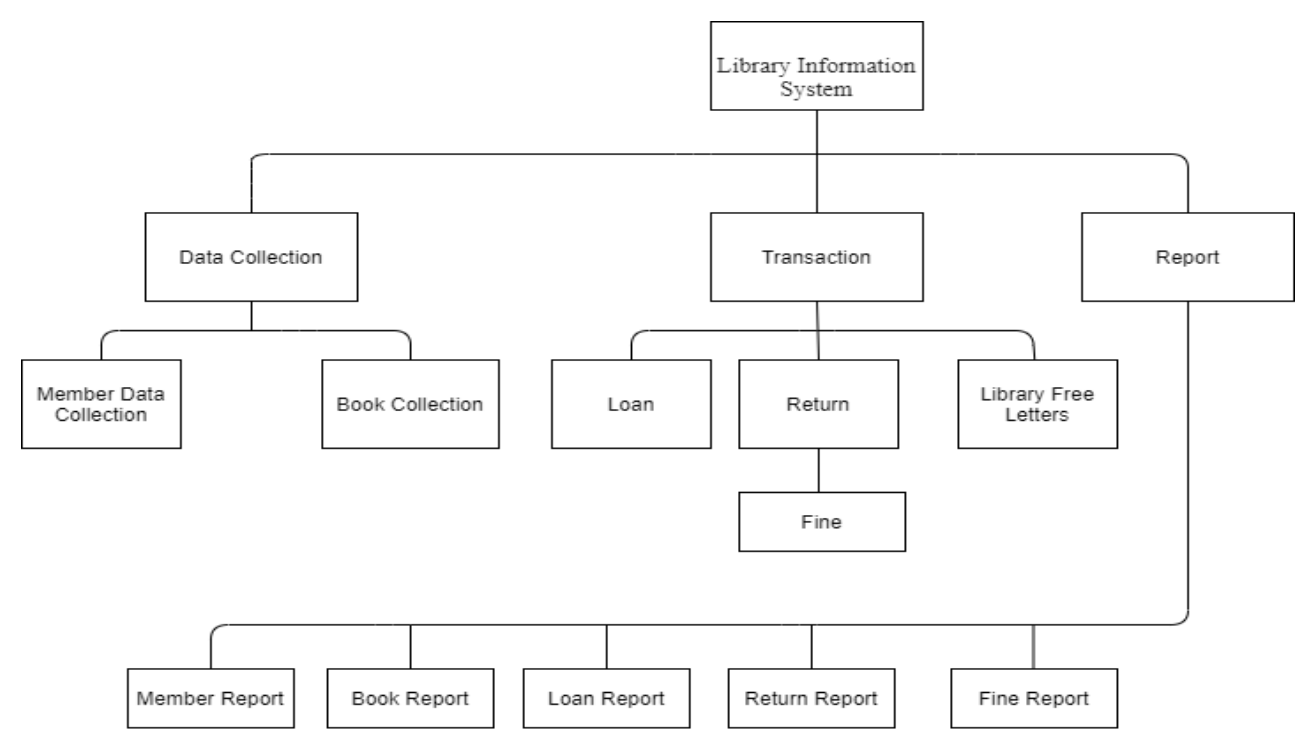

Figure 3. Library Information System

Decomposition

3. Library Transactions in Library Information System Design

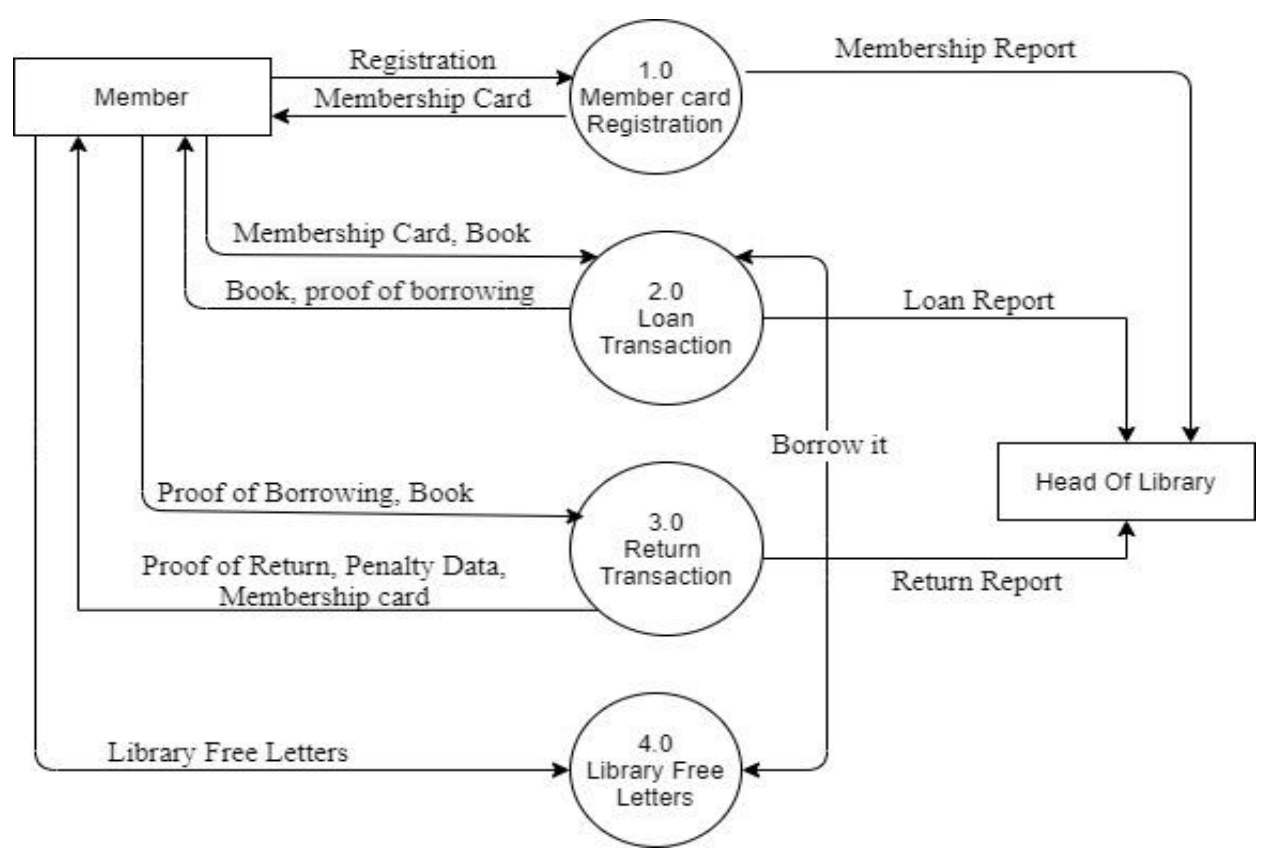

Figure 4. Transaction 
4. The security system display menu (Login Form), the security system used by officers, this form is also to protect people who do not have the authority to use this system, the information system security display system of Sunan Kalijaga Yogyakarta UIN Library.

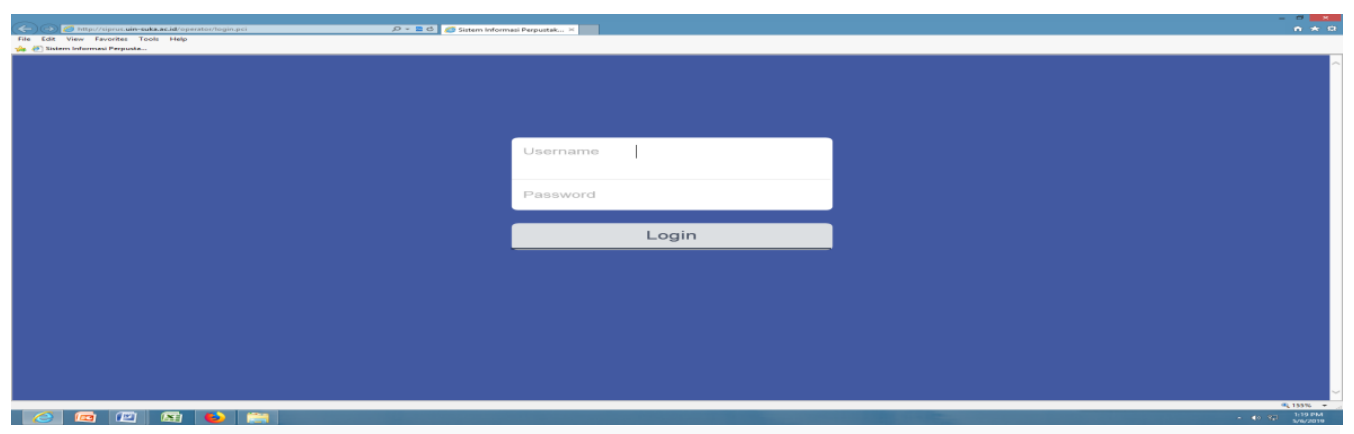

Figure 5. Login page of the Information System of the UIN Sunan Kalijaga Yogyakarta Library

5. Display list of members of the Yogyakarta State Islamic University Sunan Kalijaga Library

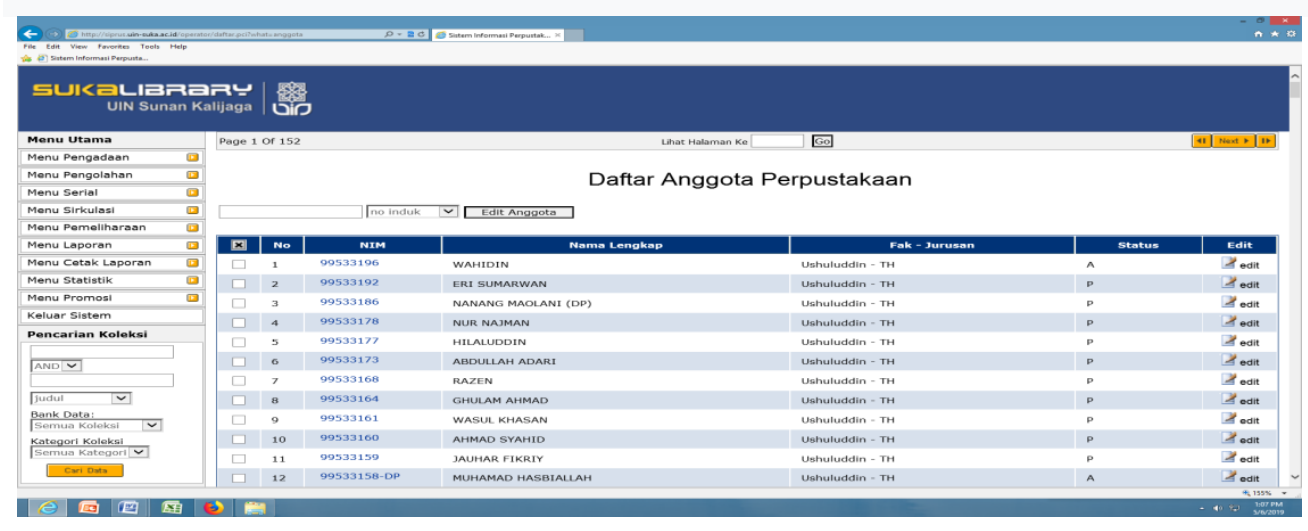

Figure 6. Members List

6. Display list of types of members of Sunan Kalijaga Yogyakarta UIN Library 


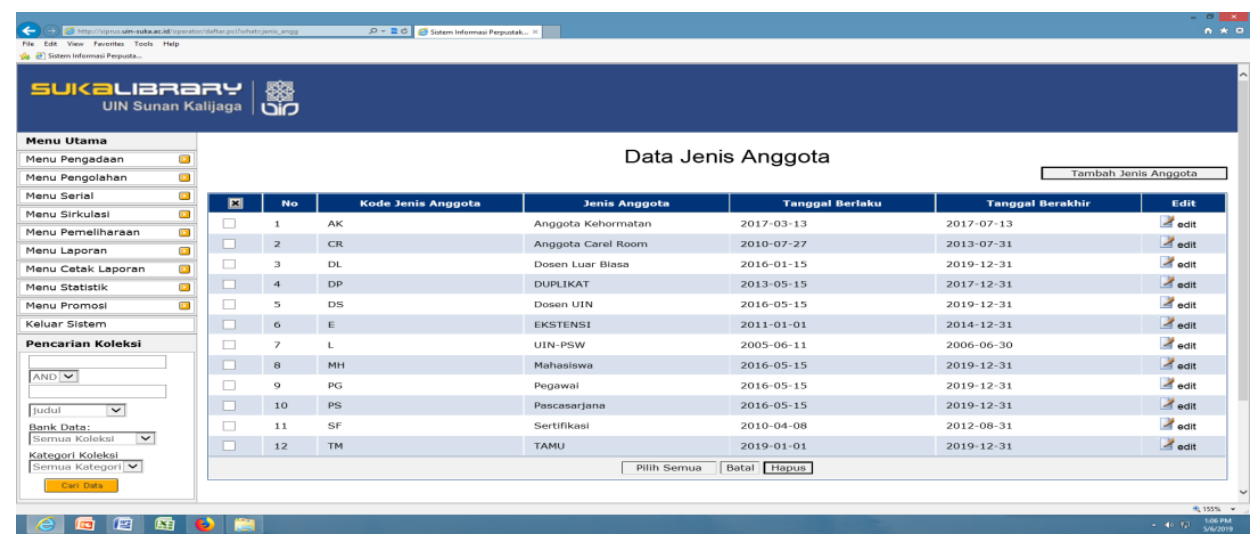

Figure 7. Member Type

7. Report of borrowing books from the library of UIN Sunan Kalijaga Yogyakarta.

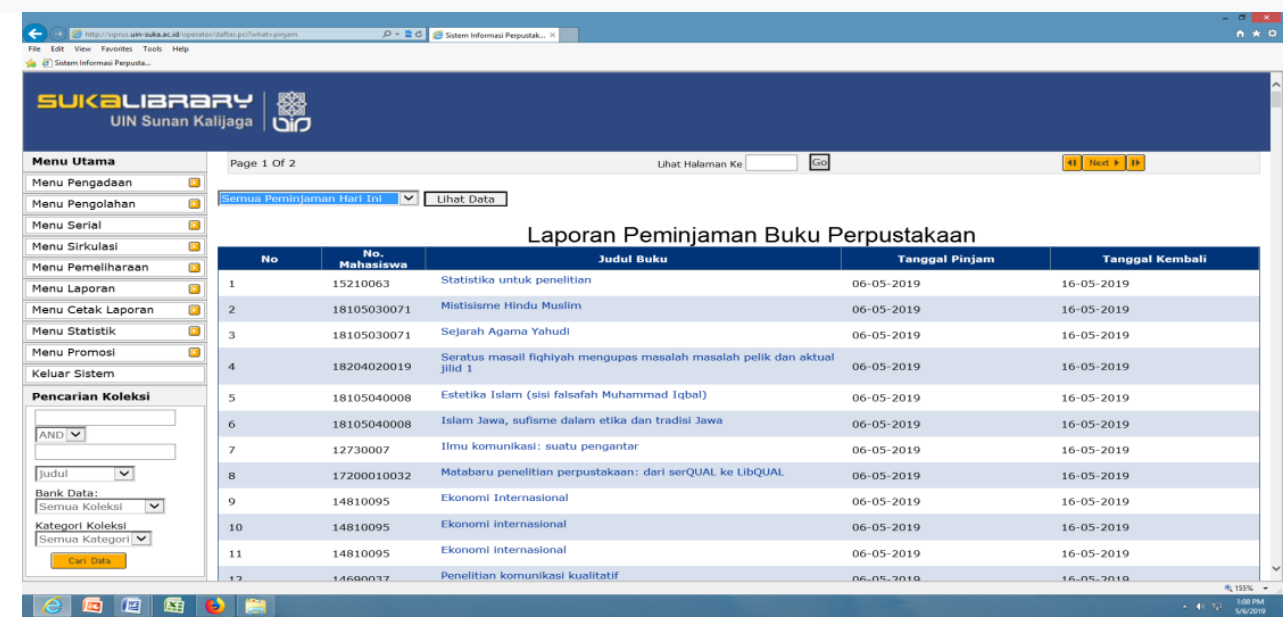

Figure 8. Loan Report

8. Report on returning books of Sunan Kalijaga UIN Library in Yogyakarta.

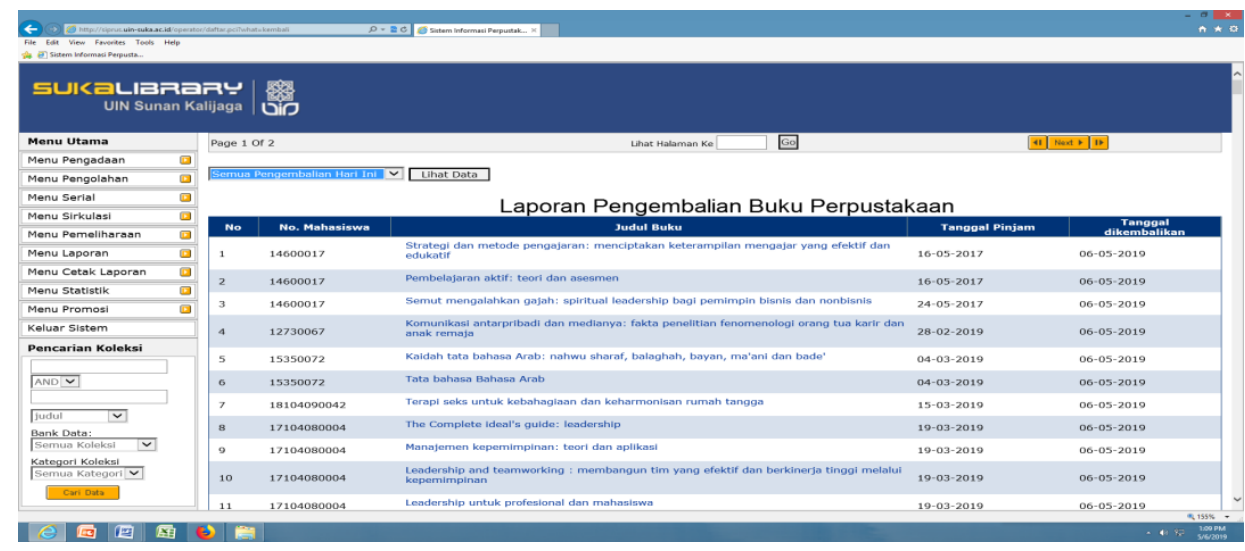


Figure 9. Report on Returning Books

9. Report the number of free members of the library of UIN Sunan Kalijaga Yogyakarta Library

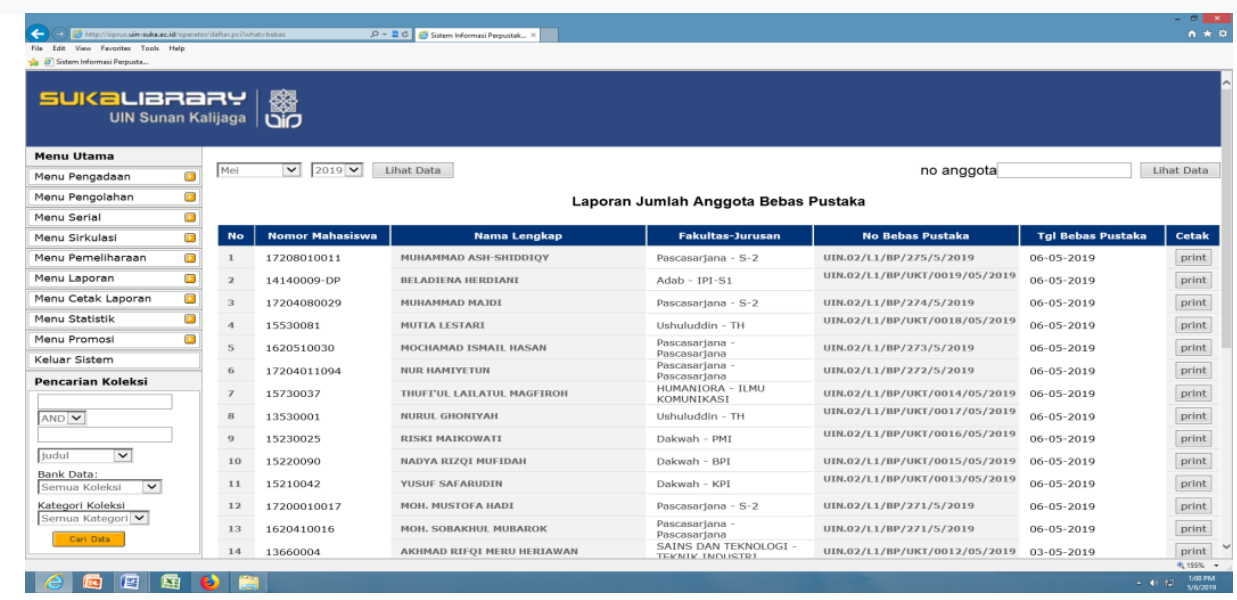

Figure 10. Report the Numbers of Free Members of The Library

Based on observations on March 6, 2020, above, we can see and present about an information system design in the library of Sunan Kalijaga Yogyakarta, among the information system designs in the form of concepts that we can see in the picture, whether it starts from a determination of data, type of data and connecting an integrated system so that it creates a relationship between table one and the other table. The above can explain that:

1. Main menu has a function to enter the information system of Sunan Kalijaga Yogyakarta UIN Library.

2. The member registration menu serves to register new members and member card printing.

3. Menu types of library members, this menu serves to find out the types of members of the Sunan Kalijaga Yogyakarta UIN Library.

4. Menu borrowing and returning library materials. 
5. Circulation menu functions for borrowing and returning books, whether borrowing is done by students, staff, and lecturers.

6. Library free menu functions to find out the type of members who have done library free registration, who have completed their studies.

Library Information System of UIN Sunan Kalijaga is often known to us with library information systems (Pak Bambang, 2020). software that we use in the library is CYPRUS (Library Information System. CYPRUS (Library Information System) is a collection of UIN Sunan Kalijaga Yogyakarta library. MY SQL is an Open Source database, CYPRUS (Library Information System) has the task of collecting, processing, preserving, the rediscovery of information, borrowing and returning books in the circulation section, has used information technology to store data and library collections.

UIN Sunan Kalijaga Yogyakarta library information system that provides information to users who are effective and efficient. The relationship with RFID we have ELIMS (Electronic Management System) is only as an Interface, this ELIMS cannot run alone without help from CYPRUS meaning that between ELIMS and CYPRUS is integrated to be used in the connecting information system of UIN Sunan Kalijaga Yogyakarta library. RFID (Radio Frequency Identification) has the advantage of being able to provide self-service for users without being accompanied by library staff. Able to provide efficient time in terms of library technology management (RFID).

Provides security/collateral for library collections at the exit and entrance that are connected with RFID technology. CYPRUS, ELIMS, and RFID have links with one another, so they cannot walk 
alone, these library information systems support each other in carrying out operations in the library.

\section{E. Conclusion}

Based on the explanation above, it can be concluded that the UIN Sunan Kalijaga Library is often familiar with library information systems, the software we use in the library is CYPRUS (Library Information System), it is based on PHP and MY SQL, PHP is a programming language and MY SQL is the name a vendor that manages the library system's database management base.

With the presence of a library information system, it can improve the quality of work of librarians, increase the speed of service to library visitors, and access information. Through the library information system, especially for librarians, it will be very helpful in terms of data collection of library collections and member registrations to minimize data errors, also, librarians can present the required reports quickly and accurately. This library information system is expected to be able to assist librarians in handling services to members quickly regarding lending, repayment, payment of fines, making libraries free, and replacing lost books. By using this system, librarians can quickly and easily present supporting administrative documents such as membership cards, book copy code labels, wardrobe labels, and book cards. Also, the library of Uin Sunan Klaijaga in Yogyakarta has RFID (Radio Frequency Identification) technology so that the use of RFID can provide independent services for users without being accompanied by library staff. 


\section{Bibliography}

Alifah, N., \& Cahyo, A. (2018). Analisis dan perancangan desain sistem informasi perpustakaan sekolah berdasarkan kebutuhan sistem. 14(1). https://doi.org/10.22146/bip.28943

Arthur M. Langer, Analysis and Design of Information System, London: Springer, 2008

Avison, D. E., \& Fitzgerald, G, Information Systems Development: Methodologies, Techniques, and Tools (3rd ed.), London: McGraw-Hill, 2006.

Abdullah, Dahlan, Merancang Aplikasi Perpustakaan Menggunakan SDLC, Lhoksumawe: Sefa Bumi Persada, 2017.

Atningsih, Suria dan Sugiarto, Hari, Perancangan Sistem Informasi Perpustakaan Digital Berbasis Web, Jakarta, Indonesian Juornal on Netwprking and Security, Vol.6, No.4, 2017.

Hartono, Manajemen Sistem Informasi Perpustakaan; Konsep, Teori, dan Implementasi, Yogyakarta, Gava Median, 2017.

Jaraoslav Pakorny, Information System Development; Business System and Services, Modeling and Development, London: Springer, 2011.

Lexy J. Moleong, Metodologi Penelitian Kualitatif, Bandung: Rosdakarya, 2008.

Pendit, Putu Laxman, Pengantar Ilmu Perpustakaan dan Informasi Suatu Pengantar Diskusi Epistitemology dan Metodologi. Jakarta: JIP-FS UI, 2003.

Nugraha, F., Teknik, D. F., Studi, P., Informasi, S., \& Kudus, U. M. (2014). Analisa dan perancangan sistem informasi perpustakaan. 5(1), 27-32.

Speed, J., \& Engineering, S. P. (2010). Pembangunan Sistem Informasi Perpustakaan Pada Perpustakaan Umum Kabupaten Pacitan Slamet Pebrianto. 2(2), 43-47.

Rahmah, Elva. Akses dan Layanan Perpustakaan Teori dan Aplikasi, Cet ke-1. Jakarta: Kencana, 2018.

Sarosa, Samiji, Metodologi Pengembangan Sistem Informasi, Jakarta Barat: Indeks, 2017.

Sugiyono, Metode Penelitian Kuantitatif, Kualitatif, dan R\&D, Bandung: Alfabeta, 2008.

Legowo, Antonius Indra, Sistem Informasi Perpustakaan Berbasis Website Dengan Menggunakan Barcode Scanner Pada SMK Negeri 3 Kendal, Semarang: Universitas Dian Nuswantoro, 2014.

Wawancaa bersama Pak Bambang, membahas tentang bagaimana sistem informasi perpustakaan Uin Sunan Kalijaga Jogyakarta, tanggal 06 Maret 2020. 